\title{
Evaluation of the Ecotoxicological Effects of Microcystis aeruginosa and Cylindrospermopsis raciborskii on Ceriodaphnia dubia Before and After Treatment with Ultrasound
}

\author{
Vivian Silva Lira • Ingritt Caroline Moreira • \\ Paulo Sérgio Tonello • Armando A. Henriques Vieira • \\ Renata Fracácio
}

Received: 18 August 2016 / Accepted: 6 December 2016/Published online: 5 January 2017

(C) Springer International Publishing Switzerland 2017

\begin{abstract}
Bodies of water contaminated by cyanobacteria and their neuro- and hepatotoxins have caused environmental and public health issues all over the world. Therefore, determining safe concentrations in water for multiple uses to protect aquatic biota and identify forms of remediation are of broad interest. In this study, we isolated strains of the cyanobacteria Microcystis aeruginosa and Cylindrospermopsis raciborskii, which produce microcystin (MC) and saxitoxin (STX), respectively. Ecotoxicological tests using suspensions of lysed lyophilizated cells with concentrations of toxins equivalent to those permitted by legislation for potability $\left(1 \mu \mathrm{g} \mathrm{L} \mathrm{L}^{-1}\right.$ for MC and $3 \mu \mathrm{g} \mathrm{L}^{-1}$ for STX) did not result in significant mortality of the model organism, Ceriodaphnia dubia, where as concentrations five times greater resulted in decreased survival for both toxins. However, reproduction was significantly reduced even in the lower concentrations, indicating that
\end{abstract}

\footnotetext{
V. S. Lira $(\bowtie)$

São Paulo State University "Júlio de Mesquita Filho" (UNESP), Avenue Three March 511, Alto da Boa Vista, Sorocaba, SP, Brazil e-mail: vivianslira@gmail.com

I. C. Moreira - A. A. Henriques Vieira Department of Botany, Laboratory of Phycology, Federal University of São Carlos (UFSCar), São Carlos, Brazil

P. S. Tonello · R. Fracácio

Institute of Science and Technology of Sorocaba (ICTS), Toxicology Laboratory of Environmental Contaminants and Histology (LATHIS), São Paulo State University "Júlio de Mesquita Filho" (UNESP), Sorocaba, Brazil
}

the currently permitted standards are not safe for environmental protection. When cyanotoxins were treated with ultrasound, mortalities were no longer significant, independent of concentrations. Although reproduction was still lower in relation to the control, it was significantly higher when compared to the results obtained before ultrasound. Ultrasound has been previously applied to cyanobacteria cell lysis, but this is the first study to investigate the ecotoxicological effects of ultrasound on cyanotoxins. Using new test organisms and different times and potency of sonication will permit the development of more efficient techniques for the remediation of these toxins and the development of more adequate parameters for the protection of aquatic life.

Keywords Microcystin - Saxitoxin . Cylindrospermopsis raciborskii $\cdot$ Microcystis aeruginosa $\cdot$ Ceriodaphnia dubia $\cdot$ Ultrasound

\section{Introduction}

Multiple sources of punctual and diffuse pollution can cause several types of injuries when they reach surface waters, including the eutrophication and consequent proliferation of potentially toxic microalgae that are responsible for environmental and public health issues. These issues have gained attention in the literature, and the presence of cyanobacteria strains with their neuroand hepatotoxins have been of special concern (Dörr et al. 2010; Rastogi et al. 2014; Mowe et al. 2015). In 
tropical regions, the predominant genera are Microcystis and Cylindrospermopsis (Mowe et al. 2015), both of which are able to produce a variety of cyanotoxins. Among these cyanotoxins, the microcystin variations (e.g., LR, RR, YR, LA, 7dmLR, WR, LF, LY, and LW), saxitoxins, neosaxitoxins, gonyautoxins (GTX14), and other analogues are particularly harmful.

The World Health Organization (WHO 2011) established the concentration of $1 \mu \mathrm{g} \mathrm{L}^{-1}$ microcystins (MC-LR) as the maximum daily concentration permitted in water appropriate for human consumption, and this amount has been used to standardize guidelines all over the world (NWQMS 2011; Health Canada 2014; US EPA 2015; Ordinance no. 2914/11 BRASIL 2015). However, the available information of the research with saxitoxins until now is not sufficient to generate limit for human consumption. Based on an event of human intoxication, Fitzgerald et al. (1999) proposed $3 \mu \mathrm{g} \mathrm{L}{ }^{-1}$ as the maximum limited acceptable in potable water, and this value was adopted, for instance, in Brazilian, Australian, and New Zealand regulations (Merel et al. 2013). Nevertheless, it is important to mention that the standards established for human life are not necessarily appropriate for the protection of aquatic life.

Since this is a subject of broad interest, it is crucial to identify forms of remediation to maintain the multiple uses of freshwater. In this context, the use of ultrasound seems to be an efficient method, since it reduces the number of algal cells and cyanobacteria and, as a consequence, limits the amount of toxins produced ( $\mathrm{Wu}$ et al. 2011; Yamamoto et al. 2015). Currently, there is no information in the literature about ecotoxicological conditions or relevant information to identify the chemical and ecotoxicological efficiency of this method. Given that, this study was based on sonicating samples from a reservoir of isolated cyanobacteria in the lab and further conducting toxicity tests after and before the sonication.

Most assays using ultrasound and cyanobacteria have often been verifications for this method in cell lysis (Pietsch et al. 2001; Okumura et al. 2007; Zagatto et al. 2012; Barrios et al. 2015; Herrera et al. 2015). Zagatto et al. (2012) is the only report for performing ecotoxicological tests after cell lysis and found increased levels of toxicity in the test organism Ceriodaphnia dubia, possibly due to released cyanotoxins. However, the effects of the ultrasound on the toxins are still unknown, and it remains unclear whether this treatment can also be used as an alternative to remediation. Therefore, an integrated approach of chemical, biological, and ecotoxicological aspects of these toxins may elucidate some of the influences that have compromised the multiple uses of aquatic environmental systems. In this study, we isolated lineages of cyanobacteria to answer the following questions: $1-$ Do the isolated lineages of cyanobacteria produce cyanotoxins? 2-Are the cyanotoxins toxic to Ceriodaphnia dubia in concentrations permitted worldwide and five times greater? 3-Are the amounts established for human consumption also adequate for protecting aquatic organisms? 4 - Can ultrasound remediate toxicity? This is the first study to investigate the effects of cyanotoxins after sonication in biological systems.

\section{Methods}

\subsection{Study Area and Sampling}

The cyanobacteria Microcystis aeruginosa and Cylindrospermopsis raciborskii were isolated from samples of surface water collected in November 2013 at the Itupararanga reservoir, São Paulo State,

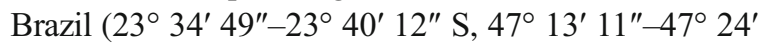
$34^{\prime \prime} \mathrm{W}$ ), using nets with $20-\mu \mathrm{m}$ pores (Fig. 1).

\subsection{Isolation and Cultivation of Cyanobacteria Lineages}

Isolation and axenization of the cyanobacteria were performed using the microcapillary technique (Anderson 2005). Organisms were grown in $8 \mathrm{~L}$ of ASM-1 medium at pH 7.0 (Gorham et al. 1964) in polycarbonate bottles with a 9-L capacity. After 5 days of culture (exponential phase), the cells were concentrated by continuous flow-refrigerated centrifuge (Heraeus model Contifuge Stratos with bomb Watson Marlow 520U) at $6000 \mathrm{rpm}$ and a flux of $25 \mathrm{~mL} \mathrm{~min}^{-1}$. The biomass obtained was frozen in liquid nitrogen and lyophilized (Heto Drywinner).

\subsection{Detection and Quantification of the Cyanotoxins}

The presence of cyanotoxins and their concentrations per milligram of lyophilized cells were determined by HPLC-MS/MS according to the methods described by Ferrão-Filho et al. (2009), which follows the recommendations of Spoof et al. (2003) for microcystins, 


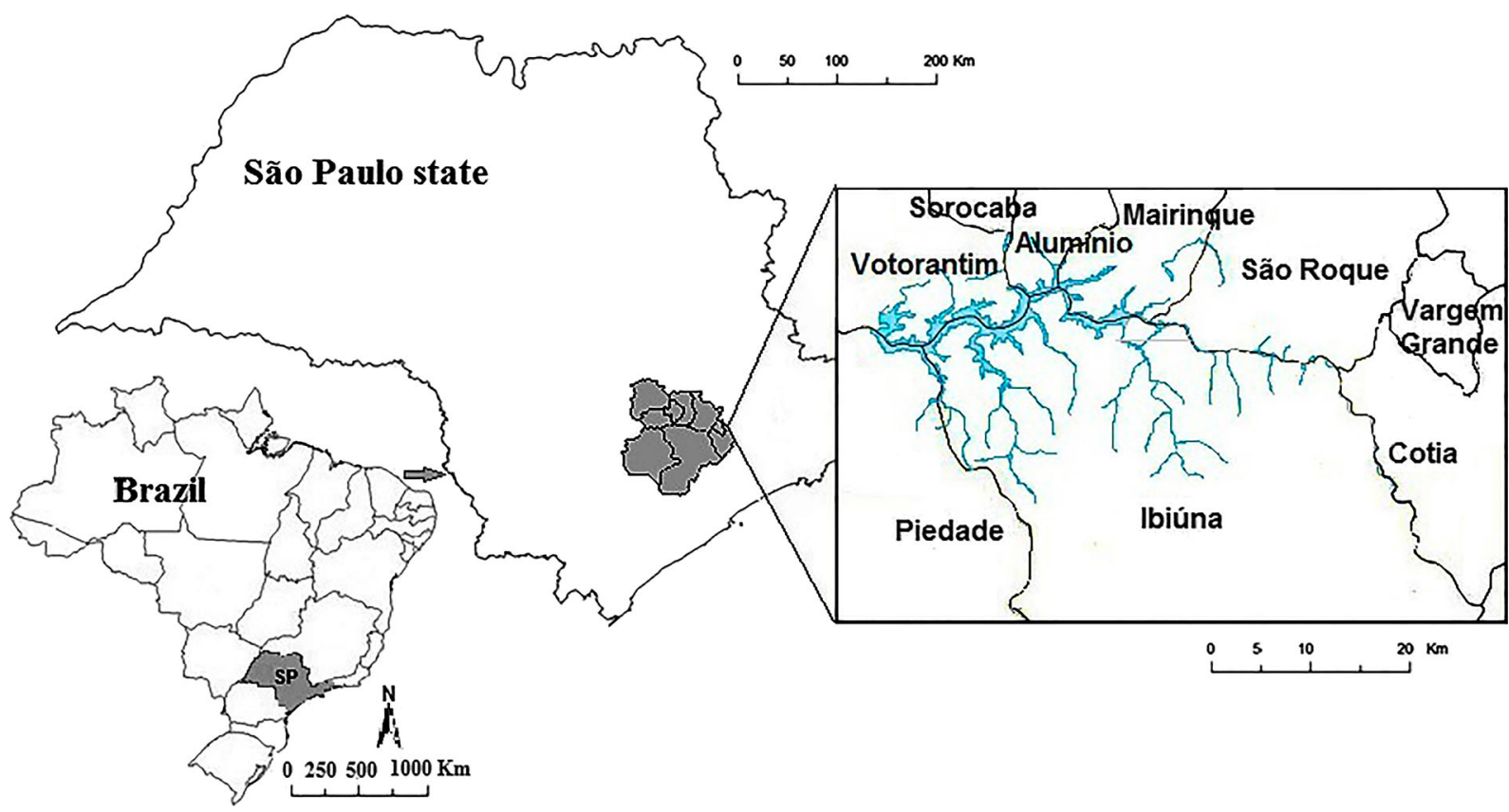

Fig. 1 Localization of the Itupararanga reservoir. Emphasis is given to the municipalities surrounding the reservoir. Source: modified from IBGE (Brazilian Institute of Geography and Statistics. Available in: http://www.ibge.gov.br/english/)

Oshima (1995) for saxitoxins, and Eaglesham et al. (1999) for cilindrospermopsins.

\subsection{Experimental Design}

The ecotoxicological experiments used two sets of stock solutions containing lyophilized cultures with equivalent concentrations of $0.02 \mathrm{mg} \mathrm{L}^{-1}$ microcystin (MC) and $0.04 \mathrm{mg} \mathrm{L}^{-1}$ saxitoxin (STX). The cyanobacterial suspensions were exposed to a cycle of freezing and thawing three times to rupture the cells, followed by their observation under an optical microscope (Zeiss Axiovert 40C) with $\times 40$ magnification to verify that the cell disruption was effective. Then, one set was sonicated for 5 min with $100 \mathrm{~W}$ power and $19 \mathrm{kHz}, 2 \mathrm{~W} \mathrm{~mL}^{-1}$ (probe sonicator Unique, model DES100; Fig. 2).

The tests were performed by exposing the model organism, Ceriodaphnia dubia, to concentrations allowed by legislations $\left(1 \mu \mathrm{g} \mathrm{L}^{-1} \mathrm{MC}\right.$ and $3 \mu \mathrm{g} \mathrm{L}^{-1}$ STX) and arbitrarily exceeding five times the concentrations (5 $\mu \mathrm{g} \mathrm{L}^{-1} \mathrm{MC}$ and $15 \mu \mathrm{g} \mathrm{L}^{-1}$ STX), using disrupted cells before and after sonication. The tests used cultivation water, which was prepared with reconstituted mineral water, $\mathrm{pH}$ varying from 7.2 to 7.6, and hardness ranging from 40 to $48 \mathrm{mg} \mathrm{CaCO}_{3}$ $\mathrm{L}^{-1}$. Control groups only used the cultivation water, and

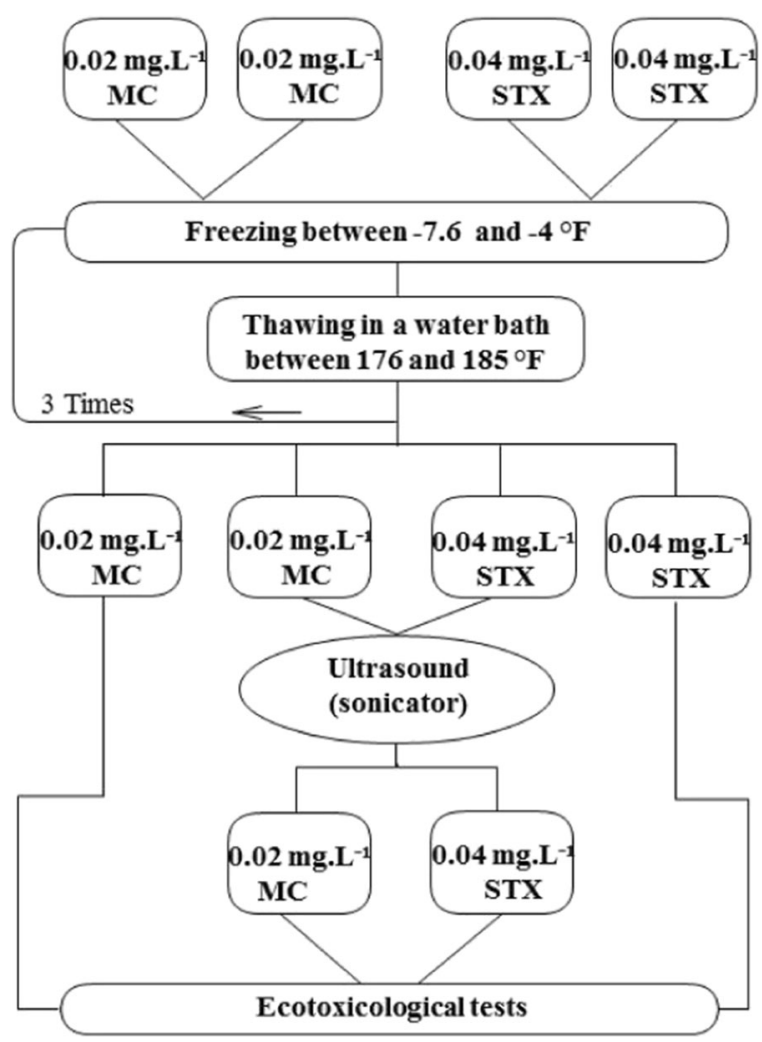

Fig. 2 Schematic of solutions preparation for ecotoxicological tests 
each treatment consisted of ten replicates containing one organism. These tests followed the recommendations from the US EPA method 1002 (2002), where test organisms with 6- to 24-h lifecycles (neonates) are used at the beginning of the experiment, and they are 8 days old at the end, as adults. The endpoints analyzed were survival and reproduction (number of neonates).

Statistical analyses were performed using the software Toxstat 3.5 (West and Gulley 1996), with the Kruskal-Wallis test to assess the potential toxicity effects in the experiments.

\section{Results and Discussion}

The cyanobacteria $M$. aeruginosa produced microcystin at a concentration of $440 \mathrm{ng} \mathrm{mg}^{-1}$, and C. raciborskii produced a concentration of $48 \mathrm{ng} \mathrm{mg}^{-1}$ saxitoxin. The presence of these toxins is similar to previous studies with these cyanobacteria, and the concentrations are within the value range found in other strains originating from Brazilian locations (Table 1), although they are not directly comparable due to the use of different methods for quantification.

Both $C$. raciborskii and $M$. aeruginosa have been frequently identified at the Itupararanga reservoir (Moschini-Carlos et al. 2007; Cunha and Calijuri 2011; Vargas 2012; Cetesb 2014, 2015), and between 2009 and 2010, they were among the phytoplanktonic organisms with higher relative densities (Cunha \& Calijuri op cit).

Without sonication, both higher concentrations of MC $\left(5 \mu \mathrm{g} \mathrm{L}^{-1}\right)$ and STX $\left(15 \mu \mathrm{g} \mathrm{L}^{-1}\right)$ significantly reduced the survival of the model organisms (Fig. 3), while lower concentrations of both substances resulted in a reduction of neonate production compared to the control (Fig. 4). According to the current Brazilian legislation (ordinance no. 2914/11 BRASIL 2015) and the WHO, the maximum permitted concentration of microcystin in potable water is $1 \mu \mathrm{g} \mathrm{L}^{-1}$. However, our data revealed that this concentration can cause adverse effects on aquatic organisms, which means this concentration is not adequate to protect aquatic life.

Sotero-Santos et al. (2008) performed acute assays with $C$. dubia using natural phytoplanktonic extracts and obtained CL50 in $48 \mathrm{~h}$ of exposition with concentrations of MC varying from 18.5 to $90 \mu \mathrm{g} \mathrm{L}^{-1}$. Negative effects of the $M$. aeruginosa lineages that produce microcystin were also detected for the development and reproduction of Daphnia (D. similoides and D. pulex), which was confirmed by Li et al. (2014).
When using lower microcystin concentrations ( 0.41 to $0.44 \mu \mathrm{g} \mathrm{L}^{-1}$ ), Barrios et al. (2015) observed a reduction in the reproduction and survival of Ceriodaphnia cornuta. Conversely, Dao et al. (2010) did not find negative impacts in chronic assays with D. magna using MC-LR $\left(5 \mu \mathrm{g} \mathrm{L}^{-1}\right)$, and Okumura et al. (2007) also did not find interference to their production or survival of $C$. silvestrii using concentrations of MC varying from 60 to $480 \mu \mathrm{g} \mathrm{g}^{-1}$ obtained from lyophilized cultures of $M$. aeruginosa.

Herrera et al. (2015) suggested that microcystin-LR obtained from natural phytoplankton extracts were probably responsible for the toxicity of $D$. similis, indicating that $83.5 \mu \mathrm{g} \mathrm{L}^{-1} \mathrm{MC}-\mathrm{LR}$ was lethal for $50 \%$ of these cladocerans after a 48-h exposure. Dao et al. (2010) showed that $50 \mu \mathrm{g} \mathrm{L}^{-1} \mathrm{MC}$-LR did not affect survival in the parental generation of D. magna, but after 2 months of exposure, it caused a $50 \%$ reduction in the population represented by the following generations. Therefore, distinct strains of cyanobacteria can present different levels of toxicity, produce different forms of microcystins or other metabolites, and produce toxic elements during the degradation of these organisms (Yang et al. 2012).

STX often reduce survival by compromising natatory movements and consequently the feeding capacity, which is typical of neurotoxins. For instance, Restani and Fonseca (2014) observed that D. laevis were immobilized after a 3 -h exposure in the range of 0.14 to $1.4 \mathrm{ng} \mathrm{L}^{-1}$ saxitoxin. Ferrão-Filho et al. (2010) also observed toxic effects in the motility of $D$. pulex exposed for $3 \mathrm{~h}$ to intact cells of $C$. raciborskii, which corresponded to approximately $2.6 \mathrm{ng} \mathrm{L}^{-1}$ STX.

Previous reports identified that a concentration of $1.37 \mathrm{ng} \mathrm{L}^{-1}$ STX caused a $50 \%$ reduction in the motility of $D$. similis after a 2-h exposure (Ferrão-Filho et al. 2014). Even smaller concentrations $\left(0.24 \mathrm{ng} \mathrm{L}^{-1}\right)$ inhibited natatory movements of $D$. pulex (Costa et al. 2013).

Zagatto et al. (2012) exposed C. dubia to different concentrations of intact and lysed cells from two lineages of $C$. raciborskii and saw a 50\% reduction in fertility with lower concentrations ( 244 cells $\mathrm{mL}^{-1}$ ) and a $100 \%$ mortality with higher concentration $\left(2.44 \times 10^{4}\right.$ cells $\left.\mathrm{mL}^{-1}\right)$. The toxic effects of $C$. raciborskii producing saxitoxins on cladocerans have also been demonstrated by FerrãoFilho et al. (2008) and Soares et al. (2009).

In this study, we found that after ultrasound treatments on the lyophilized cells, none of the substances had an effect on survival for both concentrations. However, the significant differences in reproduction compared to the control persisted in both concentrations of saxitoxin and 
Table 1 Strains of cyanobacteria isolated from Brazilian bodies of water and the cyanotoxins analyzed

\begin{tabular}{|c|c|c|c|c|}
\hline Cyanobacteria & $\begin{array}{l}\text { Concentrations of cyanotoxins } \\
\text { analyzed }\end{array}$ & $\begin{array}{l}\text { Methodology for } \\
\text { quantification }\end{array}$ & Toxicity assays performed & References \\
\hline $\begin{array}{l}\text { M. aeruginosa } \\
\text { C. raciborskii }\end{array}$ & $\begin{array}{l}440 \mathrm{ng} \mathrm{mg}^{-1} \text { of MC } \\
48 \mathrm{ng} \mathrm{mg}^{-1} \text { of STX }\end{array}$ & HPLC (lyophilized culture) & Chronic assays (C. dubia) & Present study \\
\hline M. aeruginosa & 936 to $15,000 \mu \mathrm{g} \mathrm{g}^{-1}$ of $\mathrm{MC}$ & HPLC (lyophilized culture) & $\begin{array}{l}\text { Acute assays (Daphnia } \\
\text { similis, } \\
\text { C. silvestrii, and C.dubia) }\end{array}$ & Okumura et al. (2007) \\
\hline M. aeruginosa & 674.8 to $1745.5 \mu \mathrm{g} \mathrm{L}^{-1}$ of $\mathrm{MC}$ & ELISA (liquid culture) & $\begin{array}{l}\text { Acute and chronic assays } \\
\quad(\text { C. dubia and C. silvestrii) }\end{array}$ & Takenaka (2007) \\
\hline C. raciborskii & $\begin{array}{l}0.000846 \text { to } 0.846 \mathrm{ng} \mathrm{L}^{-1} \text { of STX } \\
0.0937 \text { to } 9.37 \mathrm{ng} \mathrm{L}^{-1} \text { of STX }\end{array}$ & HPLC (liquid culture) & $\begin{array}{l}\text { Acute assays with intact } \\
\text { cells }(\text { D. pulex, } \\
\text { D. gessneri, } \\
\text { and Moina micrura })\end{array}$ & $\begin{array}{l}\text { Ferrão-Filho et al. } \\
\quad \text { (2008) }\end{array}$ \\
\hline C. raciborskii & $\begin{array}{l}32.0 \text { and } 52.0 \mathrm{mg} \mathrm{g}^{-1} \text { of STX } \\
47.7 \text { and } 55.0 \mathrm{mg} \\
\mathrm{g}^{-1} \text { of GTX1 }\end{array}$ & HPLC (lyophilized culture) & $\begin{array}{l}\text { Acute assays with intact } \\
\text { cells (Daphnia pulex } \\
\text { and Moina micrura) }\end{array}$ & $\begin{array}{l}\text { Ferrão-Filho et al. } \\
\quad(2010)\end{array}$ \\
\hline C. raciborskii & 0.25 to $2.05 \mu \mathrm{g} \mathrm{L}^{-1}$ of STX & ELISA (liquid culture) & * & Vargas (2012) \\
\hline M. aeruginosa & $\begin{array}{l}\text { Presence of variations of MC } \\
\text { (MC-RR, MC-YR, } \\
\text { MC-LR, and MC Dmt) }\end{array}$ & HPLC (lyophilized culture) & $*$ & Bortoli et al. (2014) \\
\hline C. raciborskii & 0.05 to $8.94 \mathrm{ng} \mathrm{L}^{-1}$ of STX & HPLC (liquid culture) & $\begin{array}{l}\text { Chronic assays (Daphnia } \\
\text { pulex, Daphnia gessneri, } \\
\text { and Moina micrura) }\end{array}$ & Costa et al. (2013) \\
\hline C. raciborskii & 1.37 to $10.97 \mathrm{ng} \mathrm{L}^{-1}$ of STX & HPLC (lyophilized culture) & Acute assays (D. similis) & $\begin{array}{l}\text { Ferrão-Filho et al. } \\
\text { (2014) }\end{array}$ \\
\hline C. raciborskii & 0.0014 to $14 \mathrm{ng} \mathrm{L}^{-1}$ of STX & HPLC (lyophilized culture) & Acute assays (D. laevis) & $\begin{array}{l}\text { Restani and Fonseca } \\
\text { (2014) }\end{array}$ \\
\hline
\end{tabular}

$M C$ microcystin, STX saxitoxin, * not performed

in the lower concentration of microcystin (Fig. 5). Despite the negative effect in three of the sonicated treatments (Fig. 5), the average number of neonates was higher than the assays where sonication was not used.

Several studies have addressed alternative forms of treatment for the removal and control of algae, in particular, the cyanobacteria, and techniques using ultrasound are the most efficient for controlling blooms of cells compared to other conventional techniques (Zhang et al. 2006b, 2009; Ahn et al. 2007; Wu et al. 2011; Rajasekhar et al. 2012a; Purcell et al. 2013). Zhang et al. (2009) investigated the use of sonication in the removal of $M$. aeruginosa by coagulation and confirmed the reduction of algae cells and chlorophyll $a$, without augmenting the concentration of microcystin in the water. This finding was demonstrated by Srisuksomwong et al.
Fig. 3 Survival of Ceriodaphnia dubia after 8 days of exposure to saxitoxin (STX) and microcystin (MC) solutions before sonication; significant differences $(p<0.05)$ compared to the control at the higher concentrations

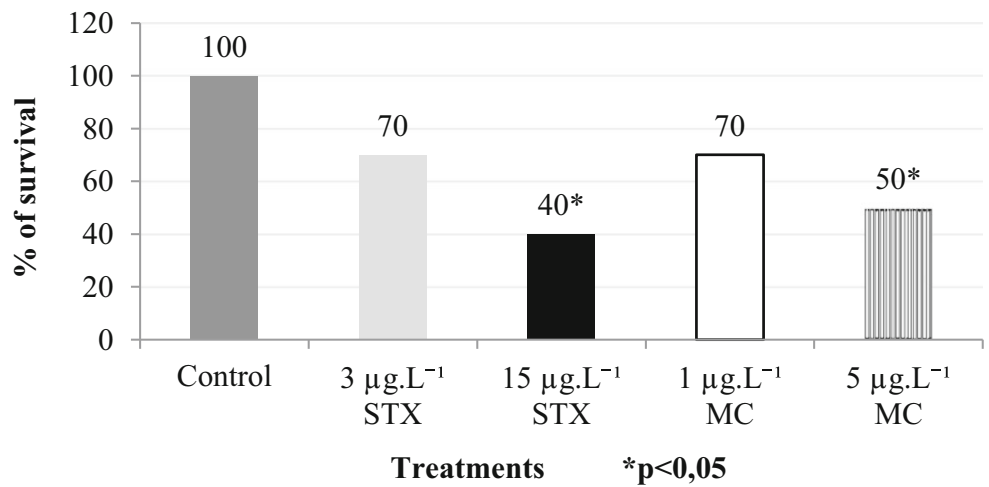




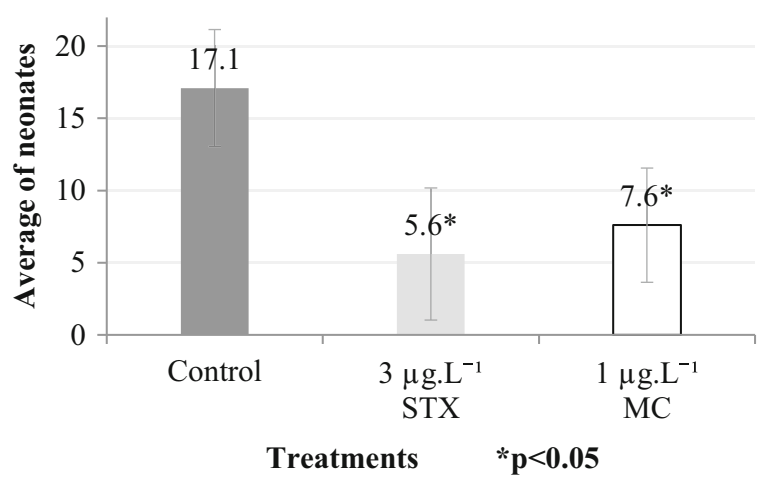

Fig. 4 Toxicity tests indicating the average number of neonates per treatment for 8 days of exposure. Bars represent standard deviations

(2011), showing a significant reduction in the amount of $\mathrm{MC}$ in natural samples of cyanobacteria that were sonicated for $10 \mathrm{~min}(3 \mathrm{~W})$ at 108 and $200 \mathrm{kHz}$, with reductions of 72.3 and $80 \%$, respectively. Rajasekhar et al. (2012b) identified a reduction of more than $60 \%$ in the number of suspended cells when exposed to $0.32 \mathrm{~W} \mathrm{~mL}^{-1}(20 \mathrm{kHz})$ for $5 \mathrm{~min}$. Similarly, Zhang et al. (2006a) showed that exposure to $0.32 \mathrm{~W} \mathrm{~mL}^{-1}(25 \mathrm{kHz})$ for $5 \mathrm{~min}$ was also efficient, since after 2 weeks, the cell concentrations were only $14.1 \%$ compared to nonsonicated cultures.

Although the works cited above have not evaluated the toxic effects after treatment, they reinforce the results of the present research by demonstrating the efficiency of ultrasound in the reduction of cells and their associated toxins. Regarding the ultrasonic frequency, $\mathrm{Wu}$ et al. (2012) obtained the best results showing that the lower frequency $(20 \mathrm{kHz})$ inactivates $M$. aeruginosa cells.

This study demonstrated a higher toxicity for the lower concentration of MC on the reproduction of the organisms. A similar result was reported by Takenaka (2007), after performing acute and chronic tests with microcystins derived from $M$. aeruginosa using $C$. dubia and C. silvestrii. We found that the lower concentrations of MC (191.87 $\left.\mu \mathrm{g} \mathrm{L}^{-1}\right)$ were more toxic than higher concentrations $\left(1194.84 \mu \mathrm{g} \mathrm{L}^{-1}\right)$. The present work did not consider other metabolites produced by cyanobacteria, such as protease inhibitors, and structural variations of the MCs, such as MC-RR, MC-LR, MC-YR, MC-LF, MC-LW (Dörr et al. 2010; Bortoli et al. 2014; Rastogi et al. 2014), STXs, and GTXs (Ferrão-Filho et al. 2010; Wiese et al. 2010; Carneiro et al. 2013). Kuster and Elert (2013) verified a negative effect in the development of D. pulex after exposure to different concentrations of the two lineages of non-MC producing M. aeruginosa, which contained the inhibitor chymotrypsin or trypsin.

\section{Conclusion}

The cyanobacteria isolated from the reservoir can indeed produce toxins. Even low concentrations of microcystin and saxitoxin caused negative effects, mainly on the reproduction of our model organism, C. dubia, suggesting that the concentrations permitted for potability are not recommended for the protection of aquatic life. However, sonication of lysed cyanobacteria was effective in reducing toxicity, which indicates that this treatment can neutralize the toxins. In water treatment, ultrasound may first cause cell lysis, releasing cyanotoxins and increasing toxicity. Thus, remediation using ultrasound relies on determining the time exposure that may be enough to cause both cell and cyanotoxin lysis. These data may have broad utility since cyanobacteria contamination is a growing problem all over the world. The use of new model organisms
Fig. 5 Average neonates by treatment after 8 days of C. dubia exposure to cyanotoxin solutions following treatment with ultrasound. Bars represent standard deviation

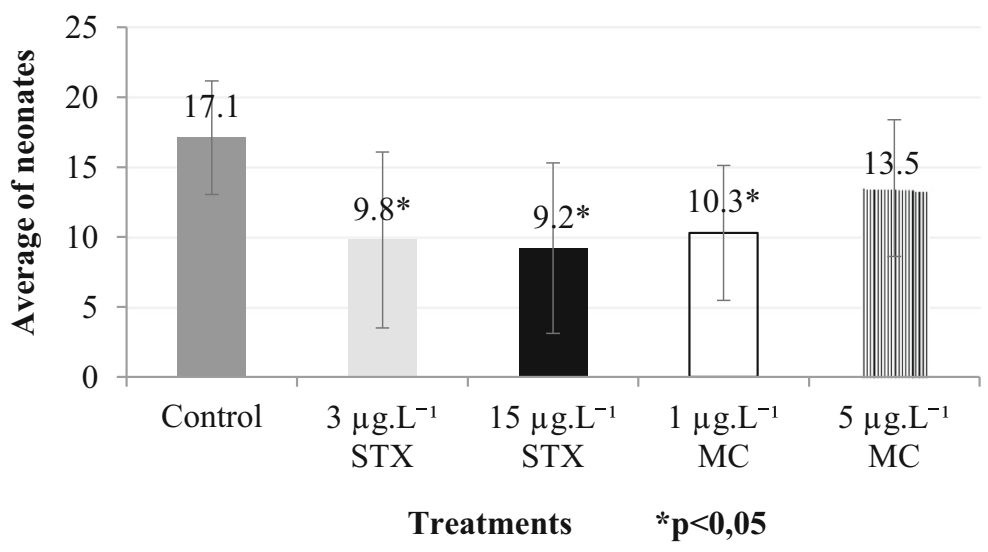


with different times and potency of sonication will further develop more efficient techniques for the remediation of these toxins.

Acknowledgments The authors are grateful to Fundação de Amparo à Pesquisa do Estado de São Paulo-FAPESP for the financial support (Proc. no. 2012/14583-5) and to E. Bertoletti and M. R. Francisco for the important suggestions on previous versions of this manuscript.

\section{References}

Ahn, C. Y., Joung, S. H., Choi, A., Kim, H. S., Jang, K. Y., \& Oh, H. M. (2007). Selective control of cyanobacteria in eutrophic pond by a combined device of ultrasonication and water pumps. Environmental Technology, 28, 371-379. doi:10.1080/09593332808618800.

Anderson, R. A. (2005). Algal culturing techniques. London, UK: Elsevier Science and Technology Books, Academic Press.

Barrios, C., Nandini, S., \& Sarma, S. (2015). Effect of crude extracts of Dolichospermum planctonicum on the demography of Plationus patulus (Rotifera) and Ceriodaphnia cornuta (Cladocera). Ecotoxicology, 24(1), 85-93. doi:10.1007/s10646-014-1358-8.

Bortoli, S., Oliveira-Silva, D., Krüger, T., Dörr, F. A., Colepicolo, P., Volmer, D. A., \& Pinto, E. (2014). Growth and microcystin production of a Brazilian Microcystis aeruginosa strain (LTPNA 02) under different nutrient conditions. Revista Brasileira de Farmacognosia, 24(4), 389-398. doi:10.1016/j.bjp.2014.07.019.

BRASIL. (2015). Ministério da Saúde. Portaria $n^{\circ} 2914$ de 12 de dezembro de 2011. Brasília: Ministério da Saúde.

Carneiro, R. L., Pacheco, A. B. F., \& Azevedo, S. M. F. O. (2013). Growth and saxitoxin production by Cylindrospermopsis raciborskii (cyanobacteria) correlate with water hardness. Marine Drugs, 11(8), 2949-2963. doi:10.3390/md11082949.

CETESB (2014). Company of Environmental Sanitation Technology. Quality report of surface water in the state of São Paulo 2013. http://www.cetesb.sp.gov.br/agua/aguas-superficiais/35publicacoes-/-relatorios. Accessed 25 November 2015.

CETESB (2015). Company of Environmental Sanitation Technology. Quality report of surface water in the state of São Paulo 2014. http://www.cetesb.sp.gov.br/agua/aguas-superficiais/35publicacoes-/-relatorios. Accessed 25 November 2015.

Costa, S. M., Ferrão-Filho, A. S., \& Azevedo, S. M. F. O. (2013). Effects of saxitoxin- and non-saxitoxin-producing strains of the cyanobacterium Cylindrospermopsis raciborskii on the fitness of temperate and tropical cladocerans. Harmful Algae, 28, 55-63. doi:10.1016/j.hal.2013.05.017.

Cunha, D. G. F., \& Calijuri, M. C. (2011). Seasonal variation of phytoplankton functional groups in the arms of a tropical reservoir with multiple uses (SP, Brazil). Acta Botânica Brasílica, 25(4), 822-831. doi:10.1590/S0102-33062011000400009.

Dao, T. S., Do-Hong, L., \& Wiegand, C. (2010). Chronic effects of cyanobacterial toxins on Daphnia magna and their offspring.
Toxicon: Official Journal of the International Society on Toxinology, 55, 1244-1254.

Dörr, F. A., Pinto, E., Soares, R. M., \& Azevedo, S. M. F. O. (2010). Microcystins in South American aquatic ecosystems: occurrence toxicity and toxicological assays. Toxicon, 56(7), 1247-1256. doi:10.1016/j.toxicon.2010.03.018.

Eaglesham, G. H., Norris, R. L., Shaw, G. R., Smith, M. J., Chiswell, R. K., Davis, B. C., Neville, G. R., Seawright, A. A., \& Moore, M. R. (1999). Use of HPLC-MS/MS to monitor cylindrosperpsin a blue-green algal toxin for public health purposes. Environmental Toxicology, 14(1), 151-154.

Ferrão-Filho, A. S., Costa, S. M., Ribeiro, M. G. L., \& Azevedo, S. M. F. O. (2008). Effects of a saxitoxin-producer strain of Cylindrospermopsis raciborskii (cyanobacteria) on the swimming movements of cladocerans. Environmental Toxicology, 23, 161-168. doi:10.1002/tox.20320.

Ferrão-Filho, A. S., Soares, M. C. S., Magalhães, V. F., \& Azevedo, S. M. F. O. (2009). Biomonitoring of cyanotoxins in two tropical reservoirs by cladoceran toxicity bioassays. Ecotoxicologyand Environmental Safety, 172, 479-489. doi:10.1016/j.ecoenv.2008.02.002.

Ferrão-Filho, A. S., Soares, M. C. S., Magalhães, V. F., \& Azevedo, S. M. F. O. (2010). A rapid bioassay for detecting saxitoxins using a Daphnia acute toxicity test. Environmental Pollution, 158, 2084-2093. doi:10.1016/j.envpol.2010.03.007.

Ferrão-Filho, A. S., Soares, M. C. S., Lima, R. S., \& Magalhães, V. F. (2014). Effects of Cylindrospermopsis raciborskii (cyanobacteria) on the swimming behavior of Daphnia (cladocera). Environmental Toxicology and Chemistry, 33, 223229. doi:10.1002/etc.2420.

Fitzgerald, D. J., Cunliffe, D. A., \& Burch, M. D. (1999). Development of health alerts for cyanobacteria and related toxins in drinking water in South Australia. Environmental Toxicology, 14(1), 203-207.

Gorham, P. R., Mclachlav, J. R., Hammer, V. T., \& Kim, W. K. (1964). Isolation and culture of toxic strains of Anabaena flos-aquae (Lyngb.) de Bréd. Verhandlungen der Internationalischen Vereinigung für Theoretische und Angewandte Limnologie, 15, 796-804.

Health Canada. (2014). Guidelines for Canadian drinking water quality-summary table. Water and air quality bureau healthy environments and consumer safety branch. Ontario: Health Canada.

Herrera, N. A., Echeverri, L. F., \& Ferrão-Filho, A. S. (2015). Effects of phytoplankton extracts containing the toxin microcystin-LR on the survival and reproduction of cladocerans. Toxicon, 95, 38-45. doi:10.1016/j.toxicon.2014.12.016.

Kuster, C., Elert, E. (2013). Interspecific differences between D. pulex and $D$. magna in tolerance to cyanobacteria with protease inhibitors. PLoS One, 8(5). doi:10.1371/journal.pone.0062658

Li, F., Deng, D., Zhang, X., Ji, G., \& Huang, Q. (2014). Combined effects of four Microcystis aeruginosa strains and Scenedesmus obliquus concentrations on population dynamics and resting egg formation of two Daphnia species. Limnology, 15(3), 271-279. doi:10.1007/s10201-014-0433-4.

Merel, S., Walker, D., Chicana, R., Snyder, S., Baurès, E., \& Thomas, O. (2013). State of knowledge and concerns on cyanobacterial blooms and cyanotoxins. Environment International, 59, 303-327. doi:10.1016/j.envint.2013.06.013.

Moschini-Carlos, V., Pedrazzi, F. J. M., Conceição, F. T., \& Pompêo, M. L. M. (2007). Water quality of the reservoir Itupararanga 
(Upper Basin of Sorocaba-SP) space vertical gradient. In Annals of the VIII Brazilian congress of ecology. Brazil: São Paulo State University "Júlio de Mesquita Filho" (UNESP).

Mowe, M. A. D., Mitrovic, S. M., Lim, R. P., Furey, A., \& Yeo, D. C. J. (2015). Tropical cyanobacterial blooms: a review of prevalence problem taxa toxins and influencing environmental factors. Journal of Limnology, 74(2), 205-224. doi:10.4081/jlimnol.2014.1005.

NWQMS. (2011). National water quality management strategyAustralian drinking water guidelines 6 (version 3.1 updated march 2015). Canberra: National Health and Medical Research Council.

Okumura, D., Sotero-Santos, R., Takenaka, R., \& Rocha, O. (2007). Evaluation of cyanobacteria toxicity in tropical reservoirs using crude extracts bioassay with cladocerans. Ecotoxicology, 16(2), 263-270. doi:10.1007/s10646-006-0126-9.

Oshima, Y. (1995). Postcolumn derivatization liquid chromatography method for paralytic shellfish toxins. Journal of AOAC International, 78, 528-532.

Pietsch, C., Wiegand, C., Ame, M. V., Nicklisch, A., Wunderlin, D., \& Pflugmacher, S. (2001). The effects of a cyanobacterial crude extract on differents aquatic organisms: evidence for cyanobacterial toxins modulating factors. Environmental Toxicology, 16(6), 535-542. doi:10.1002/tox.10014.

Purcell, D., Parsons, S. A., Jefferson, B., Holden, S., Campbell, A., Wallen, A., Chipps, M., Holden, B., \& Ellingham, A. (2013). Experiences of algal bloom control using green solutions barley straw and ultrasound an industry perspective. Water and Environment Journal, 27(2), 148-156. doi:10.1111/j.1747-6593.2012.00338.

Rajasekhar, P., Fan, L., Nguyen, T., \& Roddick, F. A. (2012a). A review of the use of sonication to control cyanobacterial blooms. Water Research, 46(14), 4319-4329. doi:10.1016/j. watres.2012.05.054.

Rajasekhar, P., Fan, L., Nguyen, T., \& Roddick, F. A. (2012b). Impact of sonication at $20 \mathrm{kHz}$ on Microcystis aeruginosa, Anabaena circinalis and Chlorella sp. Water Research, 46(5), 1473-1481. doi:10.1016/j.watres.2011.11.017.

Rastogi, R., Sinha, R. P., \& Incharoensakdi, A. (2014). The cyanotoxin-microcystins: current overview. Reviews in Environmental Science and Biotechnology, 13(2), 215-249. doi:10.1007/s11157-014-9334-6.

Restani, G. C., \& Fonseca, A. L. (2014). Effects of Cylindrospermopsis raciborskii strains (Woloszynska 1912) Senayya \& SubbaRaju on the mobility of Daphnia laevis (Cladocera Daphniidae). Brazilian Journal of Biology, 74(1), 23-31. doi:10.1590/1519-6984.09712.

Soares, M. C. S., Lürling, M., Panosso, R., \& Huszar, V. L. M. (2009). Effects of the cyanobacterium Cylindrospermopsis raciborskii on feeding and life-history characteristics of the grazer Daphnia magna. Ecotoxicologyand Environmental Safety, 72, 1183-1189. doi:10.1016/j.ecoenv.2008.09.004.

Sotero-Santos, R. B., Carvalho, E. G., Dellamano-Oliveira, M. J., \& Rocha, O. (2008). Occurrence and toxicity of an Anabaena bloom in a tropical reservoir (Southeast Brazil). Harmful Algae, 7(5), 590-598. doi:10.1016/j.hal.2007.12.017.

Spoof, L., Vesterkvist, P., Lindholm, T., \& Meriluoto, J. (2003). Screening for cyanobacterial hepatotoxins, microcystins and nodularin in environmental water samples by reversed-phase liquid chromatography-electrospray ionisation mass spectrometry. Journal of Cromatography, 1020, 105-119.
Srisuksomwong, P., Peerapornpisal, Y., Whangchai, N., Yagita, Y., Okada, K., \& Nomura, N. (2011). International. Effects of ultrasonic irradiation on degradation of microcystin in fish ponds. Journal of Agriculture and Biology, 13(1), 67-70.

Takenaka, R.A. (2007). Toxicity evaluation of Microcystis aeruginosa cultures and natural cyanobacteria blooms from reservoirs of Tietê River SP. 330p. Thesis (PhD) - School of Engineering of São Carlos University of São Paulo. São Carlos.

U.S. Environmental Protection Agency (EPA). (2002). Short-term methods for estimating the chronic toxicity of effluents and receiving waters to freshwater organism USEP. Agency Editor.

U.S. Environmental Protection Agency (EPA). (2015). Recommendations for public water systems to manage cyanotoxins in drinking water. Office of Water (4606M) EPA 815-R-15-010. Accessed 15 March 2016.

VARGAS, S. R. (2012). Influence of the concentration of nutrients in the interaction between two isolated phytoplankton species from reservoir of Itupararanga S.P. Thesis (Master of Hydraulic and Sanitation) - Area Sanitation concentration University of São Paulo São Carlos.

West Inc, \& Gulley, D. (1996). Software toxstat 3.5. Wyoming, USA: University of Wyoming.

WHO. (2011). Guidelines for drinking-water quality (4th ed.). Geneva: World Health Organization.

Wiese, M., D’Agostino, P. M., Mihali, T. K., Moffitt, M. C., \& Neilan, B. A. (2010). Neurotoxic alkaloids: saxitoxin and its analogs. Marine Drugs, 8, 2185-2211. doi:10.3390/md8072185.

Wu, X., Joyce, E., \& Mason, T. (2011). The effects of ultrasound on cyanobacteria. Harmful Algae, 10, 738-743. doi:10.1016/j.hal.2011.06.005.

Wu, X., Joyce, E. M., \& Mason, T. J. (2012). Evaluation of the mechanisms of the effect of ultrasound on Microcystis aeruginosaat different ultrasonic frequencies. Water Research, 46, 2851-2858. doi:10.1016/j.watres.2012.02.019.

Yamamoto, K., King, P. M., Wub, X., Mason, T. J., \& Joyce, E. M. (2015). Effect of ultrasonic frequency and power on the disruption of algal cells. Ultrasonics Sonochemistry, 24, 165-171. doi:10.1016/j.ultsonch.2014.11.002.

Yang, Z., Lü, K., Chen, Y., Montagnes, D. (2012). The interactive effects of ammonia and microcystin on life-history traits of the cladoceran Daphnia magna: synergistic or antagonistic? PLoS One, 7(3). doi:10.1371/journal.pone.0032285

Zagatto, P. A., Buratini, S. V., Aragão, M. A., \& Ferrão-Filho, A. S. (2012). Neurotoxicity of two Cylindrospermopsis raciborskii (cyanobacteria) strains to mice, Daphnia, and fish. Environmental Toxicology and Chemistry, 31, 857862. doi:10.1002/etc.1759.

Zhang, G., Zhang, P., Liu, H., \& Wang, B. (2006a). Ultrasonic damages on cyanobacterial photosynthesis. Ultrasonics Sonochemistry, 13, 501-505. doi:10.1016/j. ultsonch.2005.11.001.

Zhang, G., Zhang, P., Wang, B., \& Liu, H. (2006b). Ultrasonic frequency effects on the removal of Microcystis aeruginosa. Ultrasonics Sonochemistry, 13(5), 446-450. doi:10.1016/j. ultsonch.2005.09.012.

Zhang, G., Zhang, P., \& Fan, M. (2009). Ultrasound-enhanced coagulation for Microcystis aeruginosa removal. Ultrasonics Sonochemistry, 16, 334-338. doi:10.1016/j. ultsonch.2008.10.014. 